\title{
Liability of Unincorporated Divisions Under Section 1 of the Sherman Act
}

A recurrent difficulty with the application of the Sherman Act has been effective policing of single-firm activity. Traditionally, that function has been assigned to section $2^{1}$ of the Act, which makes monopoly or attempts to monopolize a crime. Section $1,^{2}$ on the other hand, theoretically proscribes agreements among firms which prevent the mechanical functioning of the market. However, the phenomenon of the corporation composed of several unincorporated divisions that control a large segment of a market may effectively vitiate the Sherman Act. So long as this firm neither attempts to nor does in fact obtain monopoly power, and so long as it does not combine with other firms to restrain trade, the antitrust laws do not hinder it from obtaining oligopoly or monopoly profits, and thereby defeating the Sherman Act's objective of promoting the impersonal operation of the market. Today, the prevalence and size of such firms, ${ }^{3}$ and the apparent ineffectiveness of section 2 in regulating their practices, ${ }^{4}$ suggest that they should be subject to section 1 liability. One way to accomplish this is to develop an intracorporate conspiracy doctrine by characterizing restrictive agreements between the divisions as conspiracies in restraint of trade.

This extension of section 1 would present problems of both construction and policy. Section 1 denominates the entity capable of engaging in a conspiracy as a "person"; section 8 of the Act $^{5}$ defines "person" as a "corporation or association." It is therefore unclear whether an unincorporated division may be a party to any conspiracy. A second and

1 15 U.S.C. § 2 (1964). In pertinent part, § 2 reads: "Every person who shall monopolize, or attempt to monopolize or combine or conspire with any other person or persons, to monopolize any part of the trade or commerce among the several states, or with foreign nations, shall be deemed guilty of a misdemeanor . . . ."

215 U.S.C. $\$ 1$ (1964). In pertinent part, § 1 reads: "Every contract, combination in the form of trust or otherwise, or conspiracy, in restraint of trade or commerce among the several States, or with foreign nations, is declared to be illegal . . . ."

3 See generally C. KAYSEN \& D. TURnER, ANTrTrust Policy 24-41 (1959), and appendices referred to therein.

4 Id. at $106-10$.

5 I5 U.S.C. $\$ 7$ (1964). The section reads: “The word 'person' or 'persons,' wherever used in sections 1-7 of this title shall be deemed to include corporations and associations existing under or authorized by the laws of either the United States . . . any State, or any foreign country." See also 15 U.S.C. $\$ 12$ (1964). 
more difficult question is whether communications between different divisions of the same corporation can properly be characterized as "conspiracies," whatever their effect on the market may be. A third and related question is whether sound policy should restrict such communications.

Until recently, allegations that an unincorporated division violated section 1 by conspiring with the corporation of which it was a part have been dismissed on the grounds that the division is an agent of the corporation and cannot conspire with the corporation because a corporation cannot conspire with itself. ${ }^{6}$ In the 1967 case of Hawaiian Oke \& Liquors, Ltd. v. Joseph E. Seagram of Sons, Inc., ${ }^{7}$ the District Court of Hawaii held that autonomous, horizontal divisions of a single corporation could conspire with each other in violation of section 1 . The court found no difference in economic effect between restraints caused by unincorporated and incorporated divisions and concluded that both should be subject to section 1 liability. Because of the significance of the divisional structure in American industry, inclusion of conspiracies between unincorporated divisions in section 1 could have substantial consequences for the administration of the antitrust laws. This comment will consider two questions: first, whether the Hawaiian Oke court was correct in discarding the traditional immunity of the unincorporated division under section 1 ; and, second, whether the test proposed by that court for deciding which divisions should be subject to liability could be improved.

Since conspiracy under the Sherman Act has traditionally been defined as concerted action by two or more persons, ${ }^{8}$ most courts have held that unincorporated divisions of a single corporation are incapable of "conspiring" under section 1, because, as part of the same person, they lack "duality." Since the corporation is one legal person, action by it and its agents alone, or by two of its agents within the scope of their employment, has been outside the scope of section $1 .{ }^{\circ}$ The prin-

6 Poller v. CBS, Inc., 284 F.2d 599 (D.C. Cir. 1960), rev'd on other grounds, 368 U.S. 464 (1962); Kemwel Automotive Corp. v. Ford Motor Co., 1966 TrADE GAs. I 71,882 (S.D.N.Y. 1966); Deterjet Corp. v. United Aircraft Corp., 211 F. Supp. 348 (D. Del. 1962); Johnny Maddox Motor Co. v. Ford Motor Co., 202 F. Supp. 103 (W.D. Tex. 1960).

7272 F. Supp. 915 (D. Hawaii 1967).

8 Union Pac. Coal Co. v. United States, 173 F. 737 (8th Cir. 1909); Alaska S.S. Co. v. International Longshoremen's Ass'n of Puget Sound, 236 F. 964 (D. Wash. 1916); United States v. MacAndrews \& Forbes Co., 149 F. 823 (C.C.S.D.N.X. 1906).

9 Nelson Radio \& Supply Co. v. Motorola, Inc., 200 F.2d 911 (5th Cir. 1952), cert. denied, 345 U.S. 925 (1953). Nelson was cited with approval in each of the cases cited note 6 supra, the division being analogized to an officer. See also Goldlawr, Inc. v. Schubert, 276 
cipal case so holding is Nelson Radio \& Supply, Inc. v. Motorola, Inc.10 Only when two corporations, and hence two persons, have acted in concert, has this necessary duality been found. Under this approach, a division may be conceptualized in either of two ways: as a non-entity composed only of the officers comprising it, in which case conspiracies by the divisions are in reality conspiracies by officers of the same corporation, and not actionable; or as an entity which is a subpart of the legal person of the corporation, in which case the division is an agent incapable of conspiring with the principal. Since the logical relationship of the whole to two of its parts and the legal relationship of principal and agent obtains in both situations, the officers-and-agents cases would be controlling under either theory.

It is, however, possible to reject the premise that the division is the equivalent of an agent and instead characterize it as the economic equivalent of a corporation. Given this characterization, cases holding that incorporated subsidiaries are not immune from section 1 become precedent for divisional liability. The principal cases supporting this view are United States v. Yellow Cab Co. ${ }^{11}$ and Kiefer-Stewart Co. v. Joseph E. Seagram of Sons, Inc., ${ }^{12}$ in which the Supreme Court held that agreements between subsidiary corporations owned by a single parent could violate section 1. Similarly, in Timken Roller Bearing Co. $v$.

F.2d 614 (3d Cir. 1960); Mackey v. Sears, Roebuck \& Co., 237 F.2d 869 (7th Cir. 1956), petition for cert. dismissed, 355 U.S. 865 (1957); Davidson v. Kansas City Star Co., 202 F. Supp. 613 (W.D. Mo. 1962); George W. Warner \& Co. v. Black \& Decker Mfg. Co., 167 F. Supp. 860 (E.D.N.Y. 1958); Herren Candy Co. v. Curtiss Candy Co., 153 F. Supp. 751 (N.D. Ga. 1957); Hudson Mattress Mfg. Co. v. Harvard Mfg. Co., 1957 TradE Cas. If 68,749 (E.D.N.Y. 1957); Sperry Rand Corp. v. Nassau Research \&: Dev. Ass'n, 152 F. Supp. 91 (E.D.N.Y. 1957); Whiteley v. Foremost Dairies, Inc., 151 F. Supp. 914 (W.D. Ark. 1957); Cott Beverage Corp. v. Canada Dry Ginger Ale, Inc., 146 F. Supp. 300 (S.D.N.Y. 1956), appeal dismissed, 243 F.2d 795 (2d Cir. 1957); Hershel Cal. Fruit Prods. Co. v. Hunt Foods, Inc., 1955 TrAdE Cas. If 67,928 (N.D. Cal. 1954); Brehm v. Goebel Brewing Co., 1953 Trade CAS. If 67,431 (W.D. Mich. 1953); Marion County Co-op. Ass'n v. Carnation Co., 114 F. Supp. 58 (W.D. Ark. 1953), aff'd, 214 F.2d 557 (8th Cir. 1954). But see White Bear Theatre Corp. v. State Theatre Corp., 129 F.2d 600, 602 (8th Cir. 1942) and Patterson v. United States, 222 F. 599, 618-19 (6th Cir.), cert. denied, 238 U.S. 635 (1915) (holding that allegations of violations of $\S \S 1$ and 2 state causes of action under both sections, as officers can conspire with, respectively, the corporation and other officers of same corporation).

10200 F.2d 911 (5th Cir. 1952), cert. denied, 345 U.S. 925 (1953).

11332 U.S. 218 (1947). A combination and conspiracy to restrain and to monopolize interstate trade in violation of $\S \S 1$ and 2 was charged against six corporate defendants and the president and controlling stockholder of the corporations, which constituted a vertically integrated enterprise. On appeal, the Supreme Court reversed the holding of the District Court that the complaint failed to state a cause of action.

12340 U.S. 211 (1951). Plaintiff, a wholesaler, charged that the Seagram and Calvert corporations, which were affiliated competitors, conspired to violate $\S 1$ by fixing maximum resale prices. Plaintiff's jury verdict, reversed by the Court of Appeals, was reinstated by the Supreme Court. 
United States, ${ }^{13}$ the Supreme Court dismissed the contention that a joint venture between commonly owned affiliates precluded a finding of a conspiracy under section 1. Timken, like the earlier case of United States $v$. General Motors Corp., ${ }^{14}$ can be said to be inapplicable because of its stress on the fact of corporate form: the opinions in both cases contain dicta stating that liability was predicated on a refusal to permit the subsidiaries to enjoy the advantages of incorporation without exposing themselves to its hazards. ${ }^{15}$ However, one may also read these cases as evincing great concern with the economic effects of permitting the form of an organization to immunize the firm from liability for price fixing or market splitting. ${ }^{16}$ Since the antitrust laws are primarily concerned with economic effect, the second reading seems more reasonable than one stressing the formality of incorporation.

Additional support for the traditional immunity may, however, be found in the words and interpretation of sections 1 and $8 .{ }^{17}$ Section 8 defines the entity capable of conspiring under section 1 as a "corpora-

13341 U.S. 593 (1951). The government charged that defendant conspired with its British and French affiliates to, inter alia, allocate trade territories and fix prices in violation of $\S 1$. The Supreme Court affirmed the district court's finding of a violation but reversed its order of divestiture.

14121 F.2d 376 (7th Cir.), cert. denied, 314 U.S. 618 (1941). The defendants were, in addition to General Motors, three subsidiary sales and financing corporations, and nineteen officers of the four corporate defendants. A violation of $\S 1$ alone was charged, on the theory that the defendants conspired and acted in concert to control the financing of the wholesale purchase and retail sale of General Motors cars. The court held that defendants' relationship as "affiliated and non-competing units engaged in a single enterprise and hence ... . in effect a single trader" was not a defense to an allegation of a conspiracy in violation of $\S 1.121$ F.2d at 404 .

15 In General Motors, the Court stated: "Nor can appellants enjoy the benefits of separate corporate identity and escape the consequences of an illegal combination in restraint of trade by insisting that they are in effect a single trader." $121 \mathrm{~F} .2 \mathrm{~d}$ at 404 . In Timken, Mr. Justice Jackson, dissenting, wrote: "It is admitted that if Timken had, within its own corporate organization, set up separate departments to operate plants in France and Great Britain, as well as in the United States, 'that would not be a conspixacy. . .' because a corporation cannot conspire with itself. Government counsel answered affirmatively the question of the Chief Justice: 'Your theory is that if you have a separate corporation, that makes the difference?" " 341 U.S. at 606. See 19 L.W. 3291 et seq. Thus, General Motors is distinguishable, since divisions do not have "the benefits of corporate identity"; and Timken may have specifically exempted such "separate departments." But see Poller v. CBS, Inc., 368 U.S. 464, 469 n.4 (1962), where the Supreme Court expressly refused to consider whether autonomous divisions came within the Timken rule.

16 Yellow $\mathrm{Cab}$ and Kiefer-Stewart stress the economic activities of the defendants. In Yellow Cab, the Supreme Court stated: "The corporate interrelationships of the conspirators ... are not determinative of the applicability of the Sherman Act. . . . The test of illegality under the Act is the presence or absence of an unreasonable restraint on interstate commerce." 332 U.S. at 227. Similarly, in Kiefer-Stewart: "Common ownership and control does not liberate corporations from the impact of the antitrust laws." 340 U.S. - at 215. .

17 See notes 2 and 5 supra. 
tion or association." The courts have brought some entities within the definition of "person" in section $8,{ }^{18}$ but this section has never been held to include unincorporated divisions. Moreover, with the exception of natural persons, subsidiary or inferior entities, such as local unions, have not been held to be within the statute. ${ }^{19}$ Corporate divisions would thus arguably be excluded from section 8 , first, because they are subtypes of a named category-"corporations"-and, second, because as subordinates in the corporate hierarchy, they lack the power to control the activities of the organization as a whole.

However, threshold definitional requirements have traditionally not impeded the regulation of activity thought to be harmful to competition. Recent Supreme Court cases concerning boycotts, ${ }^{20}$ resale price maintenance, ${ }^{21}$ and individual refusal to deal ${ }^{22}$ have seriously diluted the section 1 model of a combination by two firms to injure a third party. Moreover, as the cases on consignments indicate, principles of property law have not legalized what the Court considers to be unreasonable restraints. ${ }^{23}$ These cases, then, would sustain the view that formalities both of language and of property law may be less important

18 United States v. Wise, 370 U.S. 405 (1962) (corporate officer acting in representative capacity); UMW v. Coronado Coal Co., 259 U.S. 344 (1922) (labor union).

19 In UMW v. Coronado Coal Co., 259 U.S. 344 (1922), the court emphasized the superior position occupied by the defendant in the union's hierarchy: "The union is composed of workmen eligible to membership and is divided into districts, sub-districts and local unions. The ultimate authority is a general convention. . . . No organized corporation has greater unity of action, and in none is more power centered in the governing executive bodies." 259 U.S. at 383,385 (emphasis supplied).

20 Radiant Burners, Inc. v. Peoples Gas Light \& Coke Co., 364 U.S. 656 (1961); Klor's, Inc. v. Broadway-Hale Stores, Inc., 359 U.S. 207 (1959).

21 Simpson v. Union Oil Co., 377 U.S. 13 (1964). Cf. United States v. Arnold, Schwinn \& Co., 388 U.S. 365 (1967).

22 United States v. Parke, Davis \& Co., 362 U.S. 29 (1960). Cf. United States v. Bausch \& Lomb Optical Co., 321 U.S. 707 (1944); FTC v. Beech-Nut Packing Co., 257 U.S. 441 (1922).

23 In Simpson v. Union Oil Co., 377 U.S. 13 (1964), the Supreme Court held that a consignment agreement between Union $\mathrm{Oil}$ and its distributors that included a clause specifying a minimum resale price could violate $\S \S I$ and 2. The Court justified its use of $\S 1$ to regulate the bargaining power of the single firm by citing federal laws (i.e., the McGuire Act, 15 U.S.C. $\S 45$, and the Miller-Tydings Act, 15 U.S.C. $\S 1$ ) and Congressional hearings of the House Select Committee on Small Business. It held that while title technically remained in the consignor, the consignee bore most of the risks of ownership, and therefore the arrangement was coercive, and unenforceable. Thus the rule of property law yielded to the policy favoring limitations on market power, with that power being seen by the court as vertical integration through consignment. United States v. Arnold, Schwinn \& Co., 388 U.S. 365 (1967), while apparently a retreat from the per se thrust of Simpson, actually was governed by similar policy considerations. Here the defendant was a small company competing with large marketing chains. The Supreme Court applied the rule of reason and determined that the restraints imposed on retailers by the "Schwinn Plan" were reasonable. 
than current notions of policy. This apparent trend suggests that section 1 is to be used as a broad remedial section to police a variety of practices attacked only obliquely by other regulatory statutes. Under this theory, neither the words of section 8 nor the Nelson rule ${ }^{24}$ would prevent divisional liability.

Reconciliation of the words of the Sherman Act with divisional liability is also furthered by United States $v$. Wise, ${ }^{25}$ which held that corporate officers acting within the scope of their employment could be convicted for antitrust violations under section 1 as well as under section 14 of the Clayton Act. ${ }^{26}$ Relying on the words and the legislative history of the Sherman Act, the Supreme Court construed section 8 not to be an exclusive enumeration of the categories of potential conspirators under section $1 .{ }^{27}$ Moreover, since the sole defendants in the conspiracy held actionable in Wise were an officer acting in his representative capacity and the corporation of which he was an employee, the case may undermine the significance, if not the doctrine, of the Nelson case. ${ }^{28}$ This view of Wise is supported by the Court's res-

24 See text at note 9 supra.

25370 U.S. 405 (1962).

26 15 U.S.C. \$ 24 (1964).

27 The Court relied on the legislative history of the Sherman Act. It held that the inclusion of "corporations" in $\S 8$ was not to exclude persons, but to be certain that corporations would not be excluded from the scope of the Act, as "the doctrine of corporate criminal responsibility for the acts of officers was not well understood in 1890." 370 U.S. at 408.

28 See Brief for Appellee at 19, United States v. Wise, 370 U.S. 405 (1962). This conclusion requires a broad reading of Wise, as that case dealt specifically with the definition of "person" and did not consider the elements of a conspiracy. Thus, Wise on its facts held only that when $a \$ 1$ violation is alleged, an officer who acts solely in his representative capacity may be named as a defendant. However, since the government named as defendants only Wise and his employer, United States v. National Dairy Products Corp., 196 F. Supp. 155 (W.D. Mo. 1961), arguably a violation may be found when the only significant conspirators are a corporation and an officer thereof. This view is supported in fact, if not in theory, by the subsequent history of National Dairy, supra. Both the corporation and Wise were convicted of violating $\S 1$ and $\S 3$ of the Robinson-Patman Act, 15 U.S.C. § 13a (1964). See National Dairy Products Corp. v. United States, 350 F.2d 321, 323-24 (8th Cir. 1965), vacated on other grounds, 384 U.S. 883 (1967). In reviewing Wise's conviction under the Sherman Act count, the Court of Appeals for the Eighth Circuit held that the district court did not err in refusing to instruct that a corporation cannot be found guilty of conspiring with its own agent. This refusal was said to be consistent with Nelson because "the court required the jury to find . . . that the defendant or defendants had conspired with others-competing dairies or distributors .... The government never contended that the crimes charged rested upon a conspiracy between National and its own employees." 350 F.2d at 334. It is difficult to know whether National Dairy has honored Nelson in the breach. Since, however, the other conspirators were neither named nor prosecuted, the government was apparently able to obviate the Nelson rule by a de minimis showing of "duality." Consequently, National Dairy looks suspiciously like another example of the regulation of single-firm conduct under the guise of attacking concerted practices. $C f$. text at notes 20-23 supra. 
urrection of United States $v$. Patterson, ${ }^{29}$ which has been disapproved as an aberration from the rule stated in Nelson. ${ }^{30}$ Whatever positive implications Wise may contain for the development of conspiracy doctrine, it certainly removes section 8 as a serious bar to divisional liability. Divisions, while not within the holding in Wise, as that case was concerned solely with officers, would seem to be an a fortiori case therefrom, as they involve a less extreme piercing of the corporate veil. ${ }^{31}$ Hence, section 8 , since it describes some but not all potential conspirators under section 1 , seems a fragile bar to a rule of divisional liability.

\section{II}

Since neither precedent nor the statute clearly disposes of the issue, it is necessary to examine the policies underlying the question of divisional liability. As antitrust law is concerned with protecting competition, only those arrangements that can affect the market should be subject to liability under section $1 .^{32}$ The use of divisions to handle accounting, advertising, and legal services, or the use of a single distribution system for the marketing of several products, enables the large, integrated corporation to perform these services more economically than the smaller, non-divisional corporation. Internalization of these costs enables the large corporation to obtain efficiencies that permit sales at lower prices which benefit the consumer. Thus, a rule of divisional liability that included vertically related divisions would seem to be inconsistent with the basic antitrust policy of maximizing consumer benefits. ${ }^{33}$

Several arguments have been advanced which would, if followed, require that agreements between horizontally related divisions be immune from section 1. First, it has often been contended that it is unreasonable to require competition within the single corporate family, ${ }^{34}$

29222 F. 599 (6th Gir. 1915). Held: twenty-eight officers of a corporation could conspire with each other to violate both $\S \S 1$ and 2. See note 9 supra.

30 The Attorney General's National Committee to Study the Antitrust Laws approved the holding insofar as it was based on $\S 2$ but disapproved the alternative holding under § 1. AtT'y Gen's. Nat'l Comm. To Study the ANTITRUST LAws, Report 31 (1955).

31 Divisional liability, unlike personal liability, affords the corporate officer a measure of insulation from the Sherman Act; to that extent the piercing is less extreme.

32 See, e.g., Bork \& Bowman, The Crisis in Antitrust in The Goals of Antitrust: A Dialogue on Policy, 65 Colum. L. REv. 363 (1965).

33 See Bork, The Rule of Reason and the Per Se Concept: Price Fixing and Market Division (pt. 2), 75 YALE L.J. 373, 397-429 (1966), for an elaboration of the thesis that all vertical restraints should be lawful under the Sherman Act.

34 ATt'y Gen's. Nat'l Comm. To Study the Antitrust Laws, Report 34 (1955); McQuade, Conspiracy, Multicorporate Enterprises, and Section 1 of the Sherman Act, 41 U. VA. L. REv. 183 (1955); Rahl, Conspiracy and the Anti-Trust Laws, 44 ILL. L. REv. 743, 762$68(1950)$. 
for the subsidiaries or divisions all have the same goal: maximization of the profits of the entire enterprise. Second, it is said that the combined effect of market forces and the section 2 remedy is adequate to police single-firm conduct. So long as the market remains competitive, no one firm can fix prices successfully, for it can be undersold by competitors and thus suffer a net loss in revenue. If, however, one firm is able to dominate the market, the appropriate remedy is a section 2 and not a section 1 suit, as section 2 is specifically designed to regulate single-firm conduct that produces a non-competitive market structure. Third, it has been argued that business practices would be disrupted, as executives could not know which exchanges of information would be characterized as conspiracies. Furthermore, since section 1 makes many acts illegal per $\mathrm{se}^{35}$ only a modicum of proof would be required to find a violation, ${ }^{36}$ and the defendants would be unable to demonstrate the reasonableness of their communications. ${ }^{37}$ And fourth, it is said that there is no a priori difference between divisional and unitary structures in terms of market effect: therefore, the two should not be subject to different rules of liability. If a difference does exist, however, the divisional structure is probably superior to a unitary one: ${ }^{38}$ to discourage use of the more efficient form of organization would be contrary to sound antitrust policy. According to this view, any correlation between firm size and use of divisions is irrelevant to section 1 , because its purpose is not to regulate firm size, but to police concerted practices by more than one corporation.

None of these reasons, however, provides a satisfactory justification for immunity of horizontal divisions. The argument that members of the same corporate family should not be required to compete rests more

35 See, e.g., United States v. Socony-Vacuum Oil Co., 310 U.S. 150 (1940) (price fixing); Timken Roller Bearing Co. v. United States, 341 U.S. 593 (1951) (market splitting); Fashion Originators' Guild of America, Inc. v. FTC, 312 U.S. 457 (1940) (group boycotts); International Salt Co. v. United States, 332 U.S. 392 (1947) (tying clauses); Standard Oil Co. v. United States, 337 U.S. 293 (1949) (requirements contracts).

36 Agreement may be inferred from slight evidence of concerted action, and the per se rules then become applicable. Compare the stricter \& 2 requirements, note 49 infra.

37 For a discussion of the wisdom of the per se rule in this and similar situations, see Comment, "Combinations" in Restraint of Trade: A New Approach to Section 1 of the Sherman Act, 1966 UTAH L. REv. 75.

38 This generalization is supported empirically by the use of divisions by most large American corporations and academically by the assertion of such advantages as efficiency and the possibility of developing managerial talent more effectively than in a centralized corporate hierarchy. See generally W. Baldwin, ANtrtrust and the Changing CorporaTION, 240-75 (1961); A. Chander, STRATEgy AND Strugture (1962). For the view that executives of General Motors prefer to be trained in the decentralized divisions rather than in the centralized Chevrolet division, because the former foster the assumption of responsibility at lower levels of the corporation, see P. DRUCKER, THE CONCEPT OF THE CORPORATION 110-13 (1946). 
on the metaphor of familial togetherness than on realities of business behavior. The view of the firm as a single economic agglomeration of all the entities that it controls has been consistently rejected by the courts. ${ }^{39}$ Since the courts have discarded the classical model of the firm, there seems to be no doctrinal reason to limit the antitrust definition of the firm to one corporation, since this legal entity is not necessarily coextensive with the economic structuring of the corporation. Indeed, in many corporations today, the division and not the corporation has become the significant economic unit: it attempts to maximize profits, controls its purchasing, generates its own cost-accounting data, and performs other functions generally associated with the classical economic conception of the firm. ${ }^{40}$ This phenomenon has been recognized in recent recommendations for reporting of annual financial statements to the Securities and Exchange Commission on a divisional or productline basis. ${ }^{41}$ To the extent that, in the conglomerate or diversified firm, the division has displaced the corporation as the significant economic entity, it seems reasonable to make it the focal point of antitrust policy. This would prevent competitors within a single corporation from agreeing on the terms of their rivalry. Faced with the paradoxes of requiring intra-familial competition or sanctioning intra-familial cartels, the courts should opt for the former, as antitrust policy is legitimately concerned more with preventing injurious trade practices than with preserving the rigor of corporate jargon.

39 See text at notes 11-14 supra. If the economic model of the firm were followed (see note 40 infra), the courts would not have refused to treat the multicorporate enterprise as a single firm.

40 Under traditional analysis, the firm is a monolithic entity which alone attempts to maximize profits and within which the market is superseded; its limit on expansion is the point at which it becomes more efficient not to internalize additional transactions. (See note 52 infra). Coase, The Nature of the Firm, 4 Economica N.S. 386 (1937), reprinted in Readings IN PRICE Theory 331 (G. Stigler \& K. Boulding eds. 1952). An autonomous division will have many of these characteristics, as a description of the structure and functions of a division of General Motors indicates. While central management sets the price range within which any division may operate, each division may attempt to displace a part of the market currently supplied by another division. Moreover, the divisions have authority to make all purchasing contracts, and they bargain at arm's length with, for example, the Fisher Body Division. Thus, the market is not, contrary to the model, superseded within the corporation. Finally, Drucker estimates that the divisional manager is responsible for 95 per cent of the decisions made concerning his division. P. Drucker, The Concept of the Corporation 45-59 (1946).

41 See, e.g., discussion between Dr. John M. Blair and SEC chairman Manuel F. Cohen, Hearlags on S. Res. 191 Before the Subcomm. on Antitrust \& Monopoly of the Senate Judiciary Comm., 89th Cong., 2d Sess., pt. 5, at 1991 (1966); Schwartz, Legal Implications of Product Line Reporting, 23 Bus. LAw. 527 (1968); Financial Executives Research Foundation, Project on Financlal Reporting. by Conglomerate Companies, PrelimiNARY REPORT TO BOARD OF TrUSTEEs (Dec. 1967) (on file in University of Chicago Law Review office). 
The view that market forces and section 2 are sufficient to control single-firm conduct is inconsistent with the decisions of the Supreme Court that have discarded the economic model of the firm. ${ }^{42}$ In addition, it fails to consider imperfect competition; immunity creates a significant gap in antitrust coverage, for the monopoly power exercised by a single corporation can be substantial and yet insufficient to bring it within section $2 .^{43}$ Finally, the argument begs the question. The problem that divisional liability raises is the fundamental one whether the divisional corporation should be treated as one corporation, subject only to section 2 regulation, or as several corporations, and thus properly subject to section 1 inquiry. Those who criticize the immunity of intra-corporate activities that occur within a single corporation consider that there is no adequate remedy in situations where such activity restrains trade without violating section 2.4

The third contention-that section 1 liability would unreasonably affect business practices-seems most doubtful. First, while it is true that the language of section 1 does describe the behavior of a single firm under perfect competition, ${ }^{45}$ this fact would not seem to expose any firm to indeterminate liability for conspiracies to restrain trade. To avoid divisional liability, competitive divisions, like competitive subsidiaries today, would be required only to refrain from discussion about prices and market allocation. Second, current organizational practices make this fear unnecessary in many cases. Competing divisions may well have so little contact that a legal rule prohibiting certain inter-divisional communications would require no changes whatsoever in business practices. Third, organizational changes seem unlikely. While some corporations expressed concern over the liability of affiliates after the Timken decision, ${ }^{46}$ neither that case nor KieferStewart seems to have triggered widespread modifications in corporate structure. Just as the advantages of incorporation ${ }^{4 \tau}$ probably out-

42 See note 39 supra.

43 C. Kaysen \& D. Turner, Antrtrust Policy 106-10 (1959).

44 Kramer, Does Concerted Action Solely Between a Corporation and its Officers Acting on its Behalf in Unreasonable Restraint of Interstate Commerce Violate Section 1 of the Sherman Act?, 11 FED. B.J. 130 (1951); Comment, Intra-Enterprise Conspiracy Under the Sherman Act, 63 Yale L.J. 372 (1954).

45 Each firm is expected to "restrain trade" to its advantage. The presence of competition precludes any single firm from taking more than a competitive profit. If one characterizes the competitive efforts of the single firm as "conspiracies," the elements of a \& 1 violation have been made out. Thus, it has been argued that "a broad interpretation of the intra-enterprise conspiracy doctrine [would put multi-corporate firms] in constant violation of the antitrust laws." H. Blake \& R. Pitofsky, Cases \& Materials on ANTITRUST LAW 436 (1967).

46 ATr'y Gen's. NAT't Comm. To Study the Antitrust LAws, Report 34 (1955).

47 E.g., limited liability and taxation. See, e.g., Berle, The Theory of Enterprise Entity, 47 Colua. L. REv. 343 (1947). 
weighed the disadvantage of Sherman Act liability, the benefits of the divisional structure ${ }^{48}$ are in all likelihood more significant than the potential annoyance of an antitrust suit. Fourth, the section 1 proof requirements would seem to be especially necessary in the intra-corporate area. In this situation, a conspiracy would be most likely to go undetected, since the identity of interest among the conspirators would eliminate the possibility of one party's breaking the agreement. If, as seems probable, proof becomes increasingly difficult as the conspirators' interests become increasingly similar, then the difference, if any, should be to allow less stringent requirements of proof when the conspiracy would be more difficult to detect. Hence, immunity would hamper the government in an area where conspiracy is potentially most subtle and most durable and should be subject to the widest possible range of attack. ${ }^{49}$

The best argument against liability is that structure ipso facto has no effect on the market, and therefore the law should not distinguish on the basis of organization. One may dispute this thesis on the grounds that a divisional corporation selling several products in the same market can compete unfairly by selling one product below cost or obtaining discounts in advertising or distribution..$^{50}$ But this says only that multiproduct corporations have a competitive advantage over single-product corporations, at best an economically questionable statement. ${ }^{51}$ Granting the validity of the statement, however, advocates of immunity would still maintain that section 1 restricts anti-competitive practices and not size.

Two responses may be made to this argument. The first is based on the assumptions that section 1 does regulate the market power of the single firm and that the divisional firm is evidentiary of large size

48 See note 38 supra.

49 If the action were brought under $\S 2$, it would be necessary to show a specific intent to monopolize, United States v. Columbia Steel Co., 334 U.S. 495, 531-32 (1948), or the existence of monopoly power, United States v. E. I. duPont de Nemours \& Co., 351 U.S. 377,389 (1956). A \& 1 allegation enables the government or the treble-damages plaintiff to invoke the per se rules (see note 35 supra) and thus avoid a showing of market effect or risk a justification of the restraint. See McQuade, Conspiracy, Multicorporate Enterprises, and Section $I$ of the Sherman Act, 41 U. VA. L. REv. 183, 184-88 (1955).

50 Assuming that the multi-product company can obtain a monopoly profit on one of its products, it may drive out competitors by selling another product below cost in the short run. It may arguably obtain advantages in advertising from quantity discounts or by the transfer of good will and, in distribution, from quantity discounts.

51 If the multi-product firm sells below cost, it must absorb the loss. A competitive firm could similarly sell below cost and borrow money to compete over the short term. Thus, the advantage of the large firm would be limited to its ready supply of money and advantages in the capital market. The quantity discount argument is questionable, as the larger firm may not obtain quantity discounts in advertising. Finally, the transfer of good will from one product to another is probably an insignificant competitive advantage beyond the short term. 
because only after considerable growth does the marginal utility of adding another member to the same compartment become less than the creation of two smaller compartments. ${ }^{52}$ Such a firm will often be found in markets characterized by a high degree of concentration. In such markets, use of section 1 to prevent communications between competitors should lessen the oligopoly power often exercised by large firms. The division is the unit of liability simply as a matter of convenience. It, unlike a product-line, is likely to be organizationally identifiable; and, unlike the multi-divisional corporation, it is likely to correspond with reasonable accuracy to the economic interest being attacked. The law would use divisions, then, much as it used subsidiary corporations in the Kiefer-Stewart and Timken cases, as reasonably precise representations of distinct, conflicting interests that coexist within a single firm.

Or the divisions may be viewed as significant apart from their administrative convenience. This would perhaps require acceptance of the thesis advanced herein that in the modern divisional corporation the division, as well as the corporation, fits the classical definition of the firm. This approach would make divisional liability both a rule of convenience for attacking market power and a rule of economics based on a new perception of the organization of corporations and the structure of markets.

In summary, then, the question of divisional liability must be determined as a matter of antitrust policy. It is submitted that a rule of divisional liability is appropriate for horizontal divisions. First, this rule would enable the courts to police uses of oligopoly power that section 2 would be unable to reach. Second, it would prevent the corporation from engaging in the deceptive practice of representing its divisions to the public as competitors while restricting the scope of their competition. Third, it would recognize explicitly that courts do regulate market power under section 1 and would use the divisional structure to bring a variety of restrictive agreements within section 1 .

52 Compare an explanation of the reasons why all transactions are not carried on within a single firm: "First, as a firm gets larger, there may be decreasing returns to the entrepreneur function, that is, the costs of organising additional transactions within the firm may rise. Naturally, a point may be reached where the costs of organising an extra transaction within the firm are equal to the costs involved in carrying out the transaction in the open market, or, to the costs of organising by another entrepreneur. Secondly, it may be that as the transactions which are organised increase the entrepreneur fails to place the factors of production in the uses where their value is greatest, that is, fails to make the best use of the factors of production ... . [These] reasons . . . most probably correspond to the economists' phrase of 'diminishing returns to management.' "Coase, The Nature of the Firm, 4 Economica N.S. 386 (1937), reprinted in REAdINGs IN PricF THEORY 331, 340-41 (G. Stigler \& K. Boulding eds. 1952) (emphasis supplied). 
In so doing, the law would recognize that corporations, unlike roses, are not all alike.

\section{III}

The result, if not the reasoning, of the Hawaiian Oke case is consistent with these observations. In this treble-damages action, the plaintiff alleged a violation of section 1 and named as defendants, inter alia, the unincorporated, horizontal divisions of House of Seagram. ${ }^{53}$ In Kiefer-Stewart, the same divisions of the same corporation had been found to have conspired in violation of section 1 ; since that decision, Seagram had reorganized into unincorporated divisions. Faced with the awkward choice of departing from the traditional view or of holding that unincorporation alone conferred immunity from section 1, the Hawaii District Court held that the divisions could conspire in violation of the Sherman Act. ${ }^{54}$ It noted that the modern corporation is not necessarily a single producing unit but is often a "multi-headed Siva." "v5 It apparently assumed that the divisions were competitive $^{56}$ and attempted to determine whether the divisions could conspire on the basis that:

[T] he factual conclusion that a division has independence of action in the relevant business activity is critical to a determination that the division is legally capable of conspiring. .... ${ }^{57}$

And it attempted to discover whether a division had "independence of action" in the following way:

Is each facet of the unincorporated division's operation in fact, for all purposes, controlled and directed from above, or is it endowed with separable, self-generated and moving power to act in the pertinent area of economic activity? This is the key question. ${ }^{58}$

53 Calvert Distillers Co., Four Roses Distillers Co., and Frankfort Distillers Co. Also named as defendants were the corporation, Joseph E. Seagram \& Sons, Inc., McKesson \& Robbins, Inc., Barton Distilling Co., and Barton Western Co. For an extensive account of the Seagram organization before the decision to unincorporate, see Comment, IntraEnterprise Conspiracy Under the Sherman Act, 63 YALE L.J. 372, 382-85 (1954).

54 The court avoided the Nelson line by calling the case one of first impression and distinguished the earlier cases (see notes 6 and 9 supra) as limited to the factual situation of corporations and agents or unincorporated divisions and corporations. Hawaiian Oke \& Liquors, Ltd. v. Joseph E. Seagram \& Sons, Inc., 272 F. Supp. 915, 917-19 (D. Hawaii 1967).

55 Hawaiian Oke \& Liquors, Ltd. v. Joseph E. Seagram \&: Sons, Inc., 272 F. Supp. 915, 919 (D. Hawaii 1967).

50 Id. at 917.

57 Id. at 919 .

58 Id. at 920 . The language, by describing the divisions in human terms ("self-generated 
This test is far broader than the holding necessary to encompass conspiracies between divisions, for it makes any division or entity not totally controlled by another a potential conspirator. ${ }^{59}$ Unlike cases conferring immunity on the unincorporated division, it seeks to determine capability to conspire not by considering the defendant's structure (i.e., is it a corporation?) but by describing its functions (i.e., what does it do?). An analysis of the test, however, indicates that its drawbacks prevent the inquiry in Hawaiian Oke from being more than a new structural test.

One problem is that the definition is tautologous. The test is not an attempt to isolate those characteristics of the divisional structure which would justify or require expansion of section 1 to include the division, but is instead an effort to satisfy the arithmetic of conspiracy. This is clear from the logic of the test: in order to conspire one must be acting for oneself and not for another; a determination of "independence of action" permits the conclusion that the actor was not an agent, but was acting for himself; and those who act for themselves can conspire. ${ }^{60}$ This analysis strains the statutory language, for it requires an assumption that "person," as used in section 1, has no meaning. Since, however, "person" is specifically defined in section 8 , it is inappropriate to say that section 1 applies not to persons who conspire but to those capable of conspiring who conspire. ${ }^{61}$

and moving power to act"), supports the theory that the court is thinking largely in terms of the relationship between the officer and the corporation. While this personification of the corporation may facilitate bringing the divisions within the standard agency concepts governing divisional liability, it is largely irrelevant to the economic considerations presumably governing Sherman Act cases. For a theoretical discussion of the validity of the metaphor, see A. Nekam, The Personality Conception of the Legal Enity (1938).

59 While the court found marketing to be the "pertinent area of economic activity" in this case, its test on its face would not prevent utilization of any economic activity, no matter how narrowly defined, as the relevant factor. The court stated that: "The fact that the Seagram divisions may have certain joint or common functions does not detract from the admittedly divided responsibility for marketing. This is the only activity which must be considered in determining each division's status as a separate legal entity capable of conspiring." 272 F. Supp. at 924. Since any division would presumably have responsibility in some area, any division would be capable of conspiring under this test.

60 This line of reasoning is, furthermore, inconsistent with the court's treatment of the Nelson case. While it purports to follow the rule in Nelson that the officers of a corporation cannot conspire with each other, the test formulated by the court in Hawaiian $O k e$, being based on agency theory, would include individual as well as divisional agents. To retain immunity of the agent and still develop a theory of divisional liability, it is necessary to distinguish the economic roles of the two, and the court does not attempt to do this.

61 The court might have avoided the problem of ignoring what is a term of art by changing the definition of "corporation" in $\$ 8$. It could have held that a corporation, for antitrust purposes, means an economic unit with independence of action. Alterna- 
The test's imprecision would, moreover, facilitate formal compliance by changes that would have no relevance to the competitive relationship between divisions. Intra-corporate conspiracy involves the propriety of certain communications within a single corporation; the "independence of action" test is an attempt to determine the locus of responsibility for a given decision. Compliance would require changing the flow of communications to eliminate multiple responsibility. Corporations could insulate themselves by, for example, requiring that all inter-divisional communications be approved by a single division, such as a managing division. They could then argue that no conspiracy could have occurred because one unit made all decisions. Such a response on the part of corporations would be dysfunctional in terms of antitrust policy, since it would increase communications between the competitive divisions.

Finally, if this test were used in all cases and not only when the relationship between the divisions was clearly horizontal, the test would fail to make the distinction which is, for antitrust purposes, the crucial one; it would not bring within the scope of section I those divisions which might, if insulated, harm competition, and exclude those which could not. So applied, both vertically and horizontally related divisions could conceivably conspire to violate section 1 . This indiscriminate extension of section 1 to all intra-corporate activity would fail to recognize the difference between the horizontal and vertical relationships. ${ }^{62}$

Thus the test in Hawaiian Oke, while satisfactory for that case, is not a sufficient inquiry into the problems raised by divisional liability. Similarly, tests which would use a formal construct ${ }^{63}$ or intent ${ }^{64}$ as the criterion would be unwise. In order to protect competition, it is

tively, it could have characterized the division as an "association" and thus within the definition of "person" in \$ 8.

62 See text at note 33 supra.

63 A purely structural definition would be undesirable. This may be demonstrated by envisaging the possibility of defining the unit as the corporation defines it. This approach would be similar in method to the present system, since a corporation, by deciding to incorporate, sets the rules by which it will play: it brings itself within $\S 1$. This would have the advantage of certainty, as a corporation would always know which of its units were subject to antitrust liability and could organize its communications to comply with the law. But since the divisional label, unlike the divisional organization, confers no advantages, corporations would recast their divisions in other names or in slightly modified forms. Consequently, replacing one structural definition by another would invite a new series of semantic problems similar to these presently encountered.

04 Section 1 should apply in both situations. The arguments advanced herein are based not on motive or intent but on the anticompetitive possibilities of corporations which possess substantial market power. And antitrust policy typically looks to market effect and not to intent. Cf. United States v. Aluminum Company of America, 148 F.2d 416 (2d Cir. 1945). 
necessary to formulate a test that will not insulate the divisional corporation from section 1 , but which will predicate intrusion into the firm's conduct on the relationship between the divisions.

A possible solution would be to consider unincorporated divisions or subordinate units of a single corporation to be "persons" under section 1 when divisions or units are competitors or potential competitors; and to treat the question whether the divisions are "competitors" or "potential competitors" as one of fact. ${ }^{65}$ This approach would, unlike that in Hawaiian Oke, emphasize the regulation of agreements which could injure competition, such as inter-divisional price fixing and market splitting. The emphasis would shift from the present stress on the fact of incorporation to the policy objective of promoting and protecting a competitive market structure.

One problem that this test would present is the introduction of a threshold determination whether the divisions were competitive. Like the initial determinations in suits brought under section 7 of the Clayton Act, ${ }^{66}$ these judgments might be arbitrary. Difficulties would arise when, for example, the divisions sued produced two products having little cross-elasticity, or when the divisions serviced different geographical markets. When refusals to compete were alleged to restrain potential competition, the reasonableness of the division's activity in failing to enter a given market might become a close question. ${ }^{67}$ But the very arbitrariness of such judgments makes the lighter remedies of section 1 preferable to a section 7 suit. Moreover, this would enable corporations to obtain large size and thus have the benefit of the availability of large sums for research ${ }^{68}$ and of single service divisions.

65 It seems nearly impossible to attempt to establish, a priori, standards which would determine whether divisions were or were not in competition. The problem is similar to defining the "relevant market" in cases brought under $\S 7$ of the Clayton Act. United States v. Penn-Olin Chemical Co., 217 F. Supp. 110 (D. Del. 1963), vacated on other grounds, 378 U.S. 158 (1964) ("area of effective competition" synonymous with "relevant market" under $\S 7$ ). And these cases suggest that a gestalt approach is likely to be used. See, e.g., United States v, Grinnell Corp., 384 U.S. 563 (1956); United States v. Philadelphia National Bank, 374 U.S. 321 (1960). Given this definitional difficulty, and taking on faith the proposition that in most cases alleging a conspiracy between divisions the competitive relationship would be, as in Flawaiian Oke, an easy question, it seems preferable not to attempt to anticipate the development of the case law by suggesting standards based on dissimilar factual situations.

6615 U.S.C. \& 18 (1964). The section provides, in pertinent part: "No corporation engaged in commerce shall acquire, directly or indirectly, the whole or any part of the stock or other share capital ... of another corporation engaged also in commerce, where the effect of such acquistion may be substantially to lessen competition, or to tend to create a monopoly."

87 See FTC v. Procter \& Gamble Co., 386 U.S. 568 (1967).

88 See J. K. Galbraith, ThE NEW Industrial State $39-40$ (1967), for an exposition of the thesis that the large corporations seek to use their retained earnings for the development of new markets, thus freeing themselves from dependency on the capital market. 
While the rule would obviously create problems for the divisional corporation in determining what communications were permitted to be sent from a managing division to different horizontal divisions, this lack of certainty should be more than offset by the advantage of permitting regulation of a corporation's monopoly power without destroying the corporation in the process. Divisional liability would, then, give the government a middle ground between inaction and divestiture. This "graduated response" should benefit all concerned.

There would, moreover, be little danger that the test could be subverted by the creation of vertical divisions as intermediaries to channel communications between horizontal divisions. The Supreme Court has recently examined vertical arrangements carefully and has treated as horizontal a relationship which, though in form vertical, was effectively horizontal. ${ }^{99}$ While the difficulties of the statutory language would remain, they could be decreased either by changing the definition of "person" through the definition of "corporation" in section 8 or, following the construction made in the Wise case, ${ }^{70}$ treating section 8 as including corporations but not excluding divisions. The objection that this test affords insufficient protection from the imposition of per se violations has merit only in the marginal case where the issue of competitiveness is resolved adversely to the defendants. In most situations, competitive divisions would be aware of this fact and would therefore have notice that discussions concerning prices were illegal. Hence, a ban on concerted activity concerning prices should be neither fruitless nor unfair.

Finally, adopting this doctrine would not substantially impair efficiency. Advantages of size, such as economies of scale, vertical integration, service divisions, and research expenditures would not be affected. ${ }^{71}$ Organizational advantages of divisions should not be sig-

69 See United States v. Sealy Corp., 388 U.S. 350 (1967), where the Supreme Court held that an agreement between Sealy and its manufacturer-licensees, who owned substantially all the Sealy stock and controlled its day-to-day operations, alloting the latter exclusive territorial licenses would be treated as a horizontal agreement between the licensees, despite the vertical form of the agreement. Cf. Dr. Miles Medical Co. v. Park, 220 U.S. 373 (1911).

70 See text at note 27 supra.

71 This doctrine might, however, tend to modify the structure of large firms. Since the possession of a divisional structure and substantial market power in any single market would subject a firm to potential antitrust liability whereas the same absolute size, composed of smaller units in related but non-competitive markets, would prevent such liability, a rule of divisional liability could accelerate the present proliferation of the conglomerate firm. To the extent that the firm's expertise in the one market would not be transferable to other markets, such a trend would decrease efficiency; but this disadvantage would hopefully be offset by a lessening of concentration in any single market. Similar changes in market structure by the direct regulation of market power are anticipated by C. KAysen \& D. Turner, ANTITrust Policy 86 (1959). 
nificantly deterred, if the experience with incorporated subsidiaries is a guide. ${ }^{72}$ Any costs incurred by limiting the size or organization of a firm in a market in which it operates efficiently should be more than offset by reducing the cost to society of the exercise of monopoly power in concentrated market structures. For efficiency is promoted by protecting the market from restrictive agreements by competitors. This was the emphasis in Kiefer-Stewart: "[T] he rule [that "common ownership and control does not liberate corporations from the impact of the antitrust laws"] is especially applicable where, as here, respondents hold themselves out as competitors."'73 Implementation of the policy and protection of the market require that horizontal unincorporated divisions also be subject to section 1 liability.

\section{CoNCLUSION}

The law has limited the economic model of the firm as a monolithic, profit-maximizing entity to one corporation. In attempting to decide whether this limitation should be extended to intra-corporate activity, it is necessary to wrestle with the hybrid construct of the divisional firm, and to decide whether its activities are more appropriately characterized as single or multi-firm conduct. In the context of the Sherman Act, resolution of these questions depends on the extent to which one views section $I$ as legitimately concerned with the single corporate family, and the relationship between sections $I$ and 2 .

This comment has considered the relationship between the divisional corporation and the Sherman Act in light of two assumptions: first, that the divisonal corporation often exercises monopoly or oligopoly power; and second, that section 2 is unlikely to reach this power in most cases. Thus, it would seem sensible to extend section 1 to cover this activity if that section may appropriately police single-firm conduct or if the conduct in question may, despite its occurrence within a single corporation, be fairly described as multi-firm conduct. Since section 1 covers both a variety of vertical relationships and intraenterprise conspiracy, it cannot be said to be limited to single-firm conduct. Furthermore, the conduct and organization of the divisional corporation depart so significantly from the model of the firm as to justify treating it as more than one firm for antitrust purposes. Thus, neither doctrinal problem should restrict the courts from using section 1 to attack conspiracies by divisions.

The test offered here does not attempt to set up a new theoretical construct of the corporation, as that task is a legislative one; instead,

72 See text at note 47 supra.

73 Kiefer-Stewart Co. v. Joseph E. Seagram \& Sons, Ltd., 340 U.S. 211, 215 (1951). 
it attempts to deal with divisional liability in a pragmatic fashion. Consequently, the test is conceptually impure-both Nelson and Hawaiian Oke give clearer answers. One would make all divisions agents, the other would make all principals. Each, however, bases its approach on the law of agency. The approach attempted here has been to find an antitrust rationale by inquiring what intra-corporate structures might potentially harm competition, and bringing them within the jurisdiction of the Sherman Act. This analysis suggests that horizontal or competitive divisions should be subject to section I liability. 